\title{
Factors influencing age at menarche - a school based cross sectional study
} Narayanan Namboothiri $\mathrm{G}^{1}$, Varghese Iybu Chacko ${ }^{2}$, Anusha Rashmi ${ }^{3}$, Shreyaswi Sathyanath ${ }^{4}$, Manjula Anil ${ }^{5}$

${ }^{1}$ Post Graduate, Department of Community Medicine, A J Institute of Medical Science and Research Centre, Mangalore; ${ }^{2}$ Post Graduate, Department of Community Medicine, A J Institute of Medical Science and Research Centre, Mangalore; ${ }^{3}$ Assistant Professor, Department of Community Medicine, K S Hegde Medical Academy, Mangalore; ${ }^{4}$ Assistant Professor, Department of Community Medicine, A J Institute of Medical Science and Research Centre, Mangalore; ${ }^{5}$ Statistician, Department of Community Medicine, A J Institute of Medical Science and Research Centre, Mangalore

\begin{tabular}{|c|c|c|c|c|c|c|c|c|}
\hline Abstract & Introduction & Methodology & $\underline{\text { Results }}$ & Conclusion & References & Citation & \multicolumn{2}{|c|}{ Tables / Figures } \\
\hline \multicolumn{9}{|c|}{ Corresponding Author } \\
\hline \multicolumn{8}{|c|}{$\begin{array}{l}\text { Dr Anusha Rashmi, Assistant Professor, Department of Community Medicine, K S Hegde Medical Academy, } \\
\text { P.O Nityanandanagar, Deralakatte, Mangalore, Karnataka - } 575018 \\
\text { E Mail ID: anurash7@gmail.com }\end{array}$} & 口ifing \\
\hline
\end{tabular}

\section{Citation}

Namboothri NG, Chacko VI, Rashmi A, Shreyaswi S, Manjula A. Factors influencing age at menarche - a school based cross sectional study. Indian J Comm Health. 2020;32(2):444-446.

Source of Funding: Nil Conflict of Interest: None declared

\section{Article Cycle}

Received: 02/04/2020; Revision: 15/05/2020; Accepted: 07/06/2020; Published: 30/06/2020

This work is licensed under a Creative Commons Attribution 4.0 International License.

\section{Abstract}

Hormones, life style, animal proteins etc are factors that influence menarche. Like-wise a declining trend in age at menarche has been noticed over the past few years. This study was taken up with the objectives to study factors that are associated with menarche in our study population. Hence a school-based cross-sectional study was undertaken for the same which showed the mean age of menstruation was 12.5 years. It was significantly influenced by milk intake $(p<.05)$. Mothers' age at menarche was also found to be significantly associated with their daughters' age at menarche. Conclusion: This study provides an insight into determining factors affecting age of menarche, focusing on dietary and maternal factors. Milk consumption was found to be an important factor.

\section{Keywords}

\section{Menstruation; Menarche; Milk; Diet}

\section{Introduction}

Menarche being a life changing event is a stage of life when a girl starts changing biologically, physically and emotionally. A lot many internal and external factors contribute towards menarche. It has been noticed over the years that there has been a downward trend in the age at menarche attributed to availability of resources such as food and health related services.(1)

Although sexual precocity and timing of puberty appears earlier in girls than in boys, the issue needs to be addressed in both the genders. Self-assessment methods have been non reliable, however comparison between peers is more promising.(2)

Though it has been noted that the timing of menarche is largely under genetic control, factors such as diet, stressors etc has been seen to either accelerate or delay the maturation process.(2)

Studies have shown that consumption of animal proteins tends to alter the maturation process and thus also hastening the growth process. Surprisingly even milk is one such component. Animal proteins tend to increase IGF-1. (2,3)

In the backdrop of the above, present study was planned to find out the relationship between dietary factors and age at menarche among the high school students in the rural field practice area of a Private Medical College in Mangalore.

\section{Aims \& Objectives}

1. To assess the association between dietary factors and age of menarche of the study population

2. To assess the association between mothers age at menarche and age of menarche of the study population

\section{Material \& Methods}

A cross-sectional study was conducted among selected high schools of rural field practice area of a private institute in Mangalore. Study was conducted between January 2019 to April 2019 among children studying in Government and Private high school. All girls studying in 
8th,9th and 10th standard in the selected schools meeting the inclusion criteria was done after school permissions and parental consent. The study was conducted in 2 schools by purposive sampling within $10 \mathrm{~km}$ radius of the rural field practice area. Total students enrolled were 391 of whom 16 students were absent at the time of study conduction. The final sample size was 375 . Information was collected using a pretested semi-structured questionnaire from the students and their Mothers. Descriptive analysis along with Chi square test has been used to summarize the findings.

\section{Results}

The mean age of the students was 14 years. Majority of the participants had attained menarche at 13 years of age $(42.4 \%)$ followed by 12 years $(25.5 \%)$. Mean age at menarche was 12.5 years. Early menarche $(<12$ years of age) was observed in 21 participants (7.4\%).

(Table 1) shows that among the girl students who had attained menarche $(n=283), 255(90.1 \%)$ were non vegetarians. Intake of junk foods was seen in $61.8 \%$ (>5 times per week). Most mothers had also attained menarche at $12-13$ years. It was noted that $75.6 \%$ of the study subjects consumed milk on a regular basis compared to $24.4 \%$ who did not. Increased frequency of milk consumption was significantly associated with age at menarche $(p=.02)$ (Table 2).

\section{Discussion}

Mean age at menarche ranged from 12.8 years to 13.6 years in various studies. $(4,5)$ Our study also reveals a similar trend where mean age of menarche was 12.5 years. In accordance with the findings of the studies by Ramezani Tehrani et al (5) we also found that mothers age at menarche was a good predictor. Indian studies have also seen declining trend of menarcheal age.(6)

Al Agha et al(7)found a significant relationship between early age at puberty and consumption of animal meat. Our study did not find any significant relationship of menarche with type of diet. Around $63 \%$ of those who consume junk foods $>5$ times per week had attained menarche before 13 years of age $(p=0.91)$. A study by Anita et al $(8)$ found a correlation between the habit of consuming junk food $>2$ $x 1$ week with early age of menarche with an OR of 1.9. High fats lead to weight gain and increase in estrogen levels. A Study conducted by Goon et al(9) suggested that girls who have attained menarche are significantly heavier, have higher BMIs than pre-menstrual subjects in the same age matched group attributing the same to effects of leptin on GNRH release from hypothalamus. Our study findings did not show significant association between BMI and age at menarche.

While a study by Andrea s Wiley(3) suggests some association between milk consumption and early menarche, study by Bhattarai $\mathrm{S}(10)$ shows no such association. Our study showed there is a significant association with age at menarche and frequency of milk consumption $(p=0.02)$

\section{Conclusion}

In our study mothers age at menarche and milk consumption were significant factors. However, there are several other factors which may influence the onset age of menarche such as ethnic origin, genetic inheritance, socio economic status, weight, health status education, physical activity which needs to be studied as well.

\section{Recommendation}

More in-depth study is required to understand how the underlying factors affect the age at menarche.

\section{Limitation of the study}

Limited option amongst schools granting permission to conduct the study.

\section{Authors Contribution}

All authors have contributed as required in various phases from proposal to article write up.

\section{Acknowledgement}

We thank the schools that provided permission for conducting the study.

\section{References}

1. Wehkalampi K, Silventoinen K, Kaprio J, Dick DM, Rose RJ, Pulkkinen L, Dunkel L. Genetic and environmental influences on pubertal timing assessed by height growth. Am J Hum Biol. 2008 Jul-Aug;20(4):417-23. doi: 10.1002/ajhb.20748. PubMed PMID: 18293372; PubMed Central PMCID: PMC3769165.[PubMed]

2. Parent AS, Teilmann G, Juul A, Skakkebaek NE, Toppari J, Bourguignon JP. The timing of normal puberty and the age limits of sexual precocity: variations around the world, secular trends, and changes after migration. Endocr Rev. 2003 Oct;24(5):668-93. doi: 10.1210/er.2002-0019. Review. PubMed PMID: 14570750.[PubMed]

3. Wiley AS. Milk intake and total dairy consumption: associations with early menarche in NHANES 1999-2004. PLoS One. 2011 Feb 14;6(2):e14685. doi: 10.1371/journal.pone.0014685. PubMed PMID: 21347271; PubMed Central PMCID: PMC3038976.[PubMed]

4. Gaudineau A, Ehlinger V, Vayssiere C, Jouret B, Arnaud C, Godeau E. Factors associated with early menarche: results from the French Health Behaviour in School-aged Children (HBSC) study. BMC Public Health. 2010 Mar 30;10:175. doi: 10.1186/1471-2458-10-175. PubMed PMID: 20353570; PubMed Central PMCID: PMC2853511. [PubMed].

5. Ramezani Tehrani F, Mirmiran P, Gholami R, Moslehi N, Azizi F. Factors influencing menarcheal age: results from the cohort of tehran lipid and glucose study. Int J Endocrinol Metab. 2014 Jul;12(3):e16130. doi: 10.5812/ijem.16130. eCollection 2014 Jul. PubMed PMID: 25237321; PubMed Central PMCID: PMC4166004. [PubMed]

6. Sinha S, Srivastava JP, Sachan B, Singh RB. A study of menstrual pattern and prevalence of dysmenorrhea during menstruation among school going adolescent girls in Lucknow district, Uttar Pradesh, India. Int J Community Med Public Health. 2016 May;3(5):1200-1203

7. Al-Agha AE, Saeedi RJ, Tatwany BO. Correlation between Nutrition and Early Puberty in Girls Living in Jeddah, Saudi Arabia. J.2014;4(3)

8. Anita S, Turisna Simanjuntak Y. The Correlation between Junk Food Consumption and Age of Menarche of Elementary School Student In Gedung Johor Medan. Unnes Journal of Public Health. 2018 Jan $31 ; 7: 21-4$. 
INDIAN JOURNAL OF COMMUNITY HEALTH / VOL 32 / ISSUE NO 02 / APR - JUN 2020

9. Goon DT, Toriola AL, Uever J, Wuam S, Toriola OM. Growth status and menarcheal age among adolescent school girls in Wannune, Benue State, Nigeria. BMC Pediatr. 2010 Aug 19;10:60. doi: 10.1186/1471-2431-10-60. PubMed PMID: 20723237; PubMed Central PMCID: PMC2939625.[PubMed].
[Factors influencing age...] | Namboothri NG et al 10 Bhattarai S, Subedi S and Acharya SR. Factors Associated with Early Menarche among Adolescents Girls: A Study from Nepal. SM J Community Med. 2018; 4(1): 1028.

\section{Tables}

\section{TABLE 1 GENERAL FACTORS ASSOCIATED WITH AGE AT MENARCHE}

\begin{tabular}{|c|c|c|c|c|c|c|}
\hline & \multicolumn{3}{|c|}{ Age at menarche } & \multirow[t]{2}{*}{ Total } & \multirow[t]{2}{*}{$x^{2}$} & \multirow[t]{2}{*}{ P value } \\
\hline & 10 - 11 years & $12-13$ years & $14-15$ years & & & \\
\hline \multicolumn{7}{|l|}{ 1. Diet } \\
\hline Vegetarian & $2(10 \%)$ & $17(8.8 \%)$ & $9(12.9 \%)$ & $28(9.9 \%)$ & \multirow[t]{2}{*}{0.945} & \multirow[t]{2}{*}{0.623} \\
\hline Non vegetarian & $18(90 \%)$ & $176(91.2 \%)$ & $61(87.1 \%)$ & $255(90.1 \%)$ & & \\
\hline \multicolumn{7}{|c|}{ 2. Junk foods consumption } \\
\hline$\geq 5$ times & 12(60) & $121(62.7)$ & $42(60)$ & $175(61.8)$ & \multirow[t]{2}{*}{0.188} & \multirow[t]{2}{*}{0.909} \\
\hline$<5$ times/week & $8(40)$ & $72(37.3)$ & $28(40)$ & $108(38.2)$ & & \\
\hline \multicolumn{7}{|l|}{ 3. BMI } \\
\hline Underweight & $8(40)$ & $118(61.3)$ & $50(71.4)$ & $176(62.3)$ & \multirow[t]{4}{*}{12.013} & \multirow[t]{4}{*}{0.062} \\
\hline Normal & $10(50)$ & $71(36.7)$ & $19(27.1)$ & $100(35.3)$ & & \\
\hline Overweight & $2(10)$ & $3(1.5)$ & $1(1.5)$ & $6(2.1)$ & & \\
\hline Class I obesity & 0 & $1(0.5)$ & 0 & $1(0.35)$ & & \\
\hline Total & 20 & 193 & 70 & 283 & & \\
\hline \multicolumn{7}{|c|}{ 4. Mothers age at menarche } \\
\hline $10-11$ years & $6(26)$ & $10(5.3)$ & $4(5.6)$ & 20 & \multirow[t]{3}{*}{24.448} & \multirow[t]{3}{*}{$<0.01$} \\
\hline $12-13$ years & $13(56.5)$ & $116(61.3)$ & $33(46.4)$ & 162 & & \\
\hline $14-15$ years & $4(17.5)$ & 63(33.4) & $34(48)$ & 101 & & \\
\hline Total & 23 & 189 & 71 & 283 & & \\
\hline
\end{tabular}

\section{TABLE 2 MILK CONSUMPTION PATTERN AND ITS ASSOCIATION WITH MENARCHE}

\begin{tabular}{|c|c|c|c|c|c|c|}
\hline & \multicolumn{3}{|c|}{ Age at menarche } & \multirow[t]{2}{*}{ Total } & \multirow[t]{2}{*}{$x^{2}$} & \multirow[t]{2}{*}{$P$ value } \\
\hline & 10 - 11 years & 12 - 13 years & $\begin{array}{l}14-15 \\
\text { years }\end{array}$ & & & \\
\hline \multicolumn{7}{|c|}{ 1. Milk consumption } \\
\hline Yes & $13(65)$ & $148(76.7)$ & $54(75.7)$ & $215(75.6)$ & \multirow[t]{2}{*}{1.425} & \multirow[t]{2}{*}{0.490} \\
\hline No & $7(35)$ & $45(23.3)$ & $16(24.3)$ & $68(24.4)$ & & \\
\hline \multicolumn{7}{|c|}{ 2. Frequency of milk intake } \\
\hline$\geq 5$ times/week & $13(65)$ & $113(58.5)$ & $38(54)$ & $164(58)$ & \multirow[t]{2}{*}{7.690} & \multirow[t]{2}{*}{0.021} \\
\hline$<5$ times/week & $7(35)$ & $80(41.5)$ & $32(46)$ & $119(42)$ & & \\
\hline \multicolumn{7}{|c|}{ 3. Quantity of milk intake } \\
\hline$\leq 1$ cup/day & $16(80)$ & $188(97.4)$ & $69(98.6)$ & 209(97.9) & \multirow[t]{2}{*}{1.11} & \multirow[t]{2}{*}{0.571} \\
\hline >1cup/day & $4(20)$ & $5(2.6)$ & $1(1.4)$ & $74(2.1)$ & & \\
\hline \multicolumn{7}{|l|}{ 4. Type of milk } \\
\hline Cow milk & $18(90)$ & $184(95.3)$ & $69(98.6)$ & 271(95.8) & \multirow[t]{3}{*}{4.313} & \multirow[t]{3}{*}{0.365} \\
\hline Goat milk & $2(10)$ & $7(3.6)$ & $1(1.4)$ & $10(3.5)$ & & \\
\hline Buffalo milk & 0 & $2(1)$ & 0 & $2(0.7)$ & & \\
\hline Total & 20 & 193 & 70 & & & \\
\hline
\end{tabular}

